\title{
THE INFLUENCE OF THE PERCEPTION OF THE QUALITY OF ACCOMMODATION ESTABLISHMENTS' PRODUCT REGARDING THE CLIENTS' DESIRE TO MAKE A RETURN VISIT A COMPARISON OF THE PRODUCT QUALITY PERCEPTION WITH THE PRODUCT VALUE PERCEPTION
}

\author{
Roman ŠVEC \\ University of South Bohemia \\ Address: $\quad$ Studentská 13, CZ-37005 České Budějovice \\ Phone: $\quad+420387772846$ \\ E-mail: $\quad$ rsvec@ef.jcu.cz
Josef NAVRÁTIL, assistant professor
University of South Bohemia
Address: $\quad$ Studentská 13, CZ-37005 České Budějovice
Phone: $\quad+420387772453$
E-mail: $\quad$ josefnav@gmail.com \\ Kamil PÍCHA, assistant professor \\ University of South Bohemia \\ Address: $\quad$ Studentská 13, CZ-37005 České Budějovice \\ Phone: +420387 772706 \\ E-mail: $\quad$ kpicha@ef.jcu.cz \\ Vivian L. WHITE BARAVALLE GILLIAM \\ Institute of Instiute of Technology and Business \\ Address: $\quad$ Okružní 517/10, CZ-370 01 České Budějovice \\ E-mail: $\quad$ vivian@mail.vstecb.cz
}




\title{
THE PERCEPTION OF THE QUALITY OF ACCOMMODATION ESTABLISHMENTS' PRODUCT
}

\author{
Key words:
}

quality perception, tourism, accommodation, catering, service

\begin{abstract}
The aim of the paper is to evaluate differences in the quality perception among particular segments of demand. Data for analysis were collected by means of the questionnaire survey among clients of accommodation establishments. The research in accommodation establishments succeeded to identify four factors of the perception of quality of services provided in those establishments, when only accommodation and catering services were taken into consideration. The most important factor of evaluation of quality of services provided in accommodation establishments emerged to be the factor "environment of the accommodation establishment". Other important factors are hygiene of the accommodation establishment, service in the catering part of the accommodation establishment and quality of meals.
\end{abstract}

\section{INTRODUCTION}

The quality of the hospitality services constitutes "the ability of a product or service to satisfy the needs, requests and expectation of the client" (Zimáková, 2010). Within context of the hospitality services, we may consider the quality to be the ability of the service to satisfy the clients' requirements. These could be expressed, not expressed or not notified (Management Consulting Group, 2008). Akbaba (2006) notes that an all-embracing definition of the quality of service is not yet possible. However, at the same time, he admits that all available proposals of just such a definition revolve around the idea that it is the result of the comparison customers make between their expectations about a service and their perceptions of the way the service has been performed.

The needs of the clients evolve in time, being influenced by many factors (Beránek and Kotek, 2007). These clients come to businesses with their desires and it is the task of managers and employees is to respond to those desires in order to satisfy both sides. It is client who determines what enterprise will be successful (Foster, 2002).

The quality services is not result of coincidence; they are the result of hard work (Š́pková, 2007). The factor of quality becomes one of the main points going against ones competitors Stárek (2011). The management of quality seems to be the most important factor in preventing the loss of clients for hospitality services; this is based upon many findings, particularly in this time of decline and recession. The study undertaken by KPMG 
shows that, presently, there is no specific system of the quality management implemented in the Czech Republic, which would be oriented towards services in the hotel industry. However, the quality in this area is influenced significantly by the norms covering problems of quality management, safety and health (MMR ČR, 2010).

"Quality is conceptualized as a measure of a provider's output" (Baker \& Crompton, 2000 , p. 787) and 'the evaluations of the quality of performance are based on the tourists' perceptions of the performance of the provider" (Baker \& Crompton, 2000, p. 787). Perceived quality in tourism studies is linked with assessment of perceived quality of services, almost in all cases (e.g., Chen \& Tsai, 2007; He \& Song, 2009; Petrick, 2004a).

The intentions of revisiting a destination represent the main component of loyalty to a given destination (Weaver and Oppermann 2000). As loyalty becomes a fundamental strategic component for organizations (Chi and Qu 2008), recommendations to other people (via word-of-mouth) are one of the most often sought after types of information for people who are interested in travelling (Hui et al. 2007). A lot of attention is also given to this phenomenon in the matter of destinations as well (for the comprehensive literature review, please see Simpson and Siguaw 2008). The perceived quality belongs to the most important concepts of the influence of willingness of people to revisit a particular place (e.g.Bigné et al., 2001; He \& Song, 2009; Petrick 2004b; Yuan \& Jang, 2008).

Vogt and Fesenmaier (1995) found in their study that service providers do not understand the level at which customers evaluate their experience and tend to underrate the customer experience.

Most of the perceived value studies in tourism use the concept based upon what Zaithaml says, where "the perceived value is the consumer's overall assessment of the utility of a product based on perceptions of what is received and what is given" (Zaithaml, 1988, p. 14). Petrick, Morais and Norman (2001) concluded that "the perceived value may be an antecedent to the outcome of satisfaction" (p. 42), as well as "quality is not embedded in perceived value, but it is a direct antecedent and is generally the best predictor of perceived value" (Petrick, 2004b, p. 399). Chen and Tsai (2007, p. 1116) argue that "perceived value plays a moderating role between quality and satisfaction". Thus, perceived value is an important component of facility loyalty.

Tourism functions in relation to the accommodation as a source of the demand for accommodation and catering services as well as other related services (Gúčik a Patúš 2005). The spectre of accommodation providing businesses is broad and the requirements of 
services differ based on the different needs and preferences of particular clients (Liška, 1997).

The sphere of accommodation has become affected by the influence of globalization (Jakubíková, 2001). The effect of globalization is obvious particularly in case of large establishment in tourism centres (Štětina, 2008) and generally it influences the development of a tourist destination as well (Foret, Klusáček, 2011).

Accommodation services are provided by those establishments that are adequate for this purpose and sufficiently equipped as far as the material and technical matters and personnel (Liška, 1997). The notion of accommodation establishments signifies buildings, compounds, spaces or surfaces, where the accommodation is provided to the public (Stárek a Vaculka, 2008). Accommodation establishments are considered to be the basis of the tourism infrastructure (Rothenberger, 2006, Stárek a Vaculka, 2008, Salerno, 2010) and their services represent an inevitable basic element of tourism development (Novacká, 2010).

"Accommodation services constitute the most considerable part of the revenue in tourism, even though the accommodation establishment itself is not a destination of any trip, but only the condition of the coming for the purpose of the travel" (Ryglová, Burian, Vajčnerová, 2011). Some approaches put these services to be superior to tourism. However, such a definition is common rather among American authors (Hobson a Teaf, 1994). The European concept put accommodation and catering services on the position of basic tourism services (Orieška, 2010).

Accommodation services are related to the stay as a part of tourism and are then linked with provision of the temporary accommodation for a person away from his or her permanent address. The notion of "service" (within the hospitality industry) could comprise many activities (Metz, Grünner, Kessler, 2008). Accommodation services and its complement (catering services) are called as an industry in the outside European literature: the "hospitality industry" (e.g. Saleh, 1991; Collin, 1994; Bolela, 2003). Collin (1994) defines "hospitality" as "good care of guests" and providers of such services as "all companies participating in providing services to their guests (hotels, restaurants, pubs and other recreational or entertainment establishments)".

Czech law defines catering services as the "production, preparation or delivery of food for the purpose of serving them, particularly within business activities, serving the refreshments or serving meals as a part of the accommodation and tourism services" ( $\$ 23$, 
Act No. 258/2000 Coll.). Boarding represents not only the nutritional needs but also the possibility of becoming acquainted with some specific elements of the culture of the respective nation or region, particularly in case of the participants of international tourism (Indrová, 2004). Some authors define catering services (from the marketing point of view) as a set of products (meals or drinks) and services (the culture of dining or feasting, the service of the waiters, the atmosphere and the total impression) which mostly overlap in terms of both time and place (Middleton, 2009). Catering services represent a big branch of business all over the Europe (Horner and Swarbrooke, 2003).

Thus, the aim of the article is to assess the importance of the quality for the desire to revisit an accommodation establishment, as well as to assess the relation between the quality of the services offered by accommodation establishments and the price of these services.

\section{MATERIAL AND METHODS}

\section{The Questionnaire and Data Collection}

A questionnaire survey among clients of accommodation establishments was given in order to achieve the objectives set in this article. We have explored the quality by means of questions about the measure of satisfaction with partial elements of the quality of those provided services; that is both accommodation and catering. The task for respondents was to evaluate particular elements of the quality on the scale of one to five, where one was the best and 5 was the worst. Partial elements of quality of the accommodation and catering services were identified based upon the analysis and findings given by previous scholars (Rothenberger, 2006; Hobson \& Teaf, 1994; Metz et al., 2008; Saleh, 1991; Collin, 1994; Bolela, 2003; Middleton, 2009). We have identified five basic elements regarding the quality of the accommodation services: the attractiveness of the environment of the accommodation establishment (U1), the equipment of the accommodation unit (U2), the services of the reception desk (U3), the services in the accommodation unit (U4), as well as the hygiene of the environment (U5). There are also the six basic elements of the quality of the services in catering: the attitude of the attendants (S1), the velocity of the service (S2), the equipment of the establishment (S3), the hygiene of the establishment (S4), the sensory properties of the meals (S5) and the variety of the offer (S6).

As a measure of destination loyalty we used the willingness to return, which was identified by asking the following question: Will you stay again in the same establishment 
in case of your return visit to the now visited area? This was measured on a five-point Likert scale $(1=$ Definitely not, 5 = Definitely yes $)$.

To be able to measure the price-to-quality ratio, we asked the respondents as follows: Evaluate the measure of the adequate ratio of the offered services quality and the demanded price. Two options for answer were: (1) The quality of the offered services is higher than the common standard for the offered price and (2) The quality of the offered services is higher than the common standard for the offered price. When a respondent was unable to make a choice, that answer was not processed any further.

Visitors were indentified based upon the demographic and behaviouristic segmentation criteria. Among demographic criteria we have opted for sex and age (in categories 15-17, 18-26, 27-35, 36-50, 51-63, above 64). The behaviouristic criteria correspond with the main criteria that are important for the participation in tourism (Navrátil, Pícha, Hřebcová, 2010): duration of the stay in number of nights $(1-2,3-4,5-6,7$ and more), the repeating rate of the return visit (the first visit, the second visit, the third visit, the fourth visit or multiple visits), the main purpose of the travel (rest, entertainment, sport, business, employment, attending lessons or classes) and whether the person is alone or accompanied (with boyfriend/girlfriend, with family, with a business partner, with friends, or with an organized group).

The collection of data proceeds from methods used for studying the perception of the environment of the nature trails (Navrátil, Knotek, Švec, Pícha, Navrátilová, 2011). The questionnaires were given out by owners or operators of the accommodation establishment having been left at reception desks by prior arrangement and subsequently distributed to guests. The guests were asked to fill the form and hand it in back before their leaving.

The collection of data was done from 2009 to 2011 in selected establishments. This survey concerned the three most widespread types of accommodation establishment in a model tourist region (South Bohemia). Then it was a matter of the hotels, guest houses and campsites. The selection of particular locations took into the consideration the space differentiation of accommodation establishment concerned tourist region (Navrátil, Švec, Pícha, Doležalová, 2012) - Bechyně, Hluboká nad Vltavou, Chlum u Třeboně, Planá nad Lužnicí, Nová Bystřice, Písek, Strakonice, Tábor, Veselí nad Lužnicí). The distribution comprised 2000 questionnaires, the return was 1291 (i.e. ca. 62\%). 


\section{Data Analysis}

Collected data were analysed using factor analysis based on the Principal Component Analysis Method (Meloun, Militký, Hill, 2005). Only those factors with eigenvalue bigger than 1 were further analysed (Tipping, Bishop, 1999). Value of the factor of the quality perception was calculated as an arithmetic average of answers on partial questions with the factor load bigger than 0.6 .

The impact of the visitors' expectations regarrding the assessment of quality of respective accommodation establishment was identified by means of the one-factor analysis of variance. The results of this analysis were tested by the Tukey Post-hoc Test for unequal sample sizes, with regard to the unequal number of respondents in particular types of accommodation establishment (Zvára, 2004).

These factors were considered as independent variables influencing the willingness of the guests to return (a dependent variable). The selection of these factors of willingness to return was decided by means of the multiple linear regression (Nusair and Hua 2010; Navrátil and Pícha, 2012) using the Forward Selection Method for Independent Variables. The first run of the Forward Selection was performed. Then the data were purged from outliers. Consequently, the process of forward selection was repeated. The model was assessed based upon the partial regression graphs and partial residual graphs and the method was assessed by means of F-test of importance of a regression model (Meloun and Militký 2006). The calculations were done separately for particular types of accommodation.

The perception of the ratio of the perceived quality to the demanded price was evaluated for particular types of accommodation and demand segments using the test for conformity in the frequencies of answer, more precisely using the Chi-square test. We used the Yates's correction in all necessary cases (Quinn, Keough, 2002).

All computations were performed using STATISTICA 10.0 software package.

\section{RESULTS AND DISCUSSION}

\section{Factors of perception of quality}

Measured quality of services offered by observed accommodation establishments consist of four elements (Table 1). Loaded with items "environment of the accommodation establishment" and "equipment of the accommodation establishment", the factor "environment of accommodation establishment" explains the biggest part of the variability (26.13\%). Second strongest factor called "hygiene in accommodation establishment" is 
loaded by variables "hygiene of premises of catering establishment", "environment of the catering establishment" and "services quality in accommodation unit" explains $14.59 \%$ of variability. Third factor was called "service in catering part of establishment" and explains $9.9 \%$ of variability of data. This factor is loaded by variables "quality of service in catering establishment" and "quickness of attendants in catering establishment". Fourth and last factor with eigenvalue bigger than 1 is "quality of meals" that explains $9.7 \%$ of variability of data. For detailed structure of results see Švec et al. (2012).

Table 1: The factors of Assessment of the Quality of the supply of the Accommodation establishments

\begin{tabular}{|c|c|c|c|c|}
\hline & $\begin{array}{c}1^{\text {st }} \text { factor } \\
\text { The } \\
\text { Environment of } \\
\text { the } \\
\text { Accommodation } \\
\text { establishment }\end{array}$ & $\begin{array}{c}2^{\text {nd }} \text { factor } \\
\text { The hygiene in } \\
\text { Accommodation } \\
\text { establishment }\end{array}$ & $\begin{array}{l}3^{\text {rd }} \text { factor } \\
\text { The Service in } \\
\text { the Catering } \\
\text { Part of the } \\
\text { establishment }\end{array}$ & $\begin{array}{l}4^{\text {th }} \text { factor } \\
\text { The } \\
\text { Quality of } \\
\text { the meals }\end{array}$ \\
\hline $\begin{array}{l}\text { The Environment of } \\
\text { Accommodation } \\
\text { Establishment }\end{array}$ & 0.799 & . & . & . \\
\hline $\begin{array}{l}\text { The Equipment of the } \\
\text { Accommodation Unit }\end{array}$ & 0.767 & . & . & . \\
\hline $\begin{array}{l}\text { The Hygiene of the Premises } \\
\text { of the Catering Establishment }\end{array}$ & . & 0.749 & . & . \\
\hline $\begin{array}{l}\text { The Environment of the } \\
\text { Catering Establishment }\end{array}$ & . & 0.727 & . & . \\
\hline $\begin{array}{l}\text { The Quality of the Services in } \\
\text { the Accommodation Unit }\end{array}$ & & 0.654 & . & . \\
\hline $\begin{array}{l}\text { The Quality of the Service in } \\
\text { the Catering Establishment }\end{array}$ & & & 0.805 & . \\
\hline $\begin{array}{l}\text { The Velocity of the attendants } \\
\text { in the Catering Establishment }\end{array}$ & & . & 0.800 & \\
\hline The Quality of the meals & . & & & 0.884 \\
\hline Eigenvalue & 2.874 & 1.606 & 1.089 & 1.071 \\
\hline$\%$ of explained variability & 26.130 & 14.596 & 9.901 & 9.736 \\
\hline
\end{tabular}

\section{The Impact of the Quality Perception on the Willingness to Make a Return Visit}

The differences in the perception of the quality factors among particular types of accommodation establishments were identified for all four types of perception (Table 2). That is why the model of the impact of quality perception on the willingness to revisit was calculated separately for particular types of types of accommodation establishments (AE). 
Table 2: The differences in factors of quality perception among particular types of accommodation facilities (averages marked with the same letter do not significantly differ one from another according the Tukey Post-hoc Yest for unequal sample sizes, $\mathrm{p}<0,05$; SD $=$ standard deviation).

\begin{tabular}{|l|c|c|c|c|c|c|c|c|c|c|c|}
\hline & \multicolumn{3}{|c|}{ Hotels } & \multicolumn{3}{c|}{ Guest houses } & \multicolumn{3}{c|}{ Campsites } & & \\
\hline & Average & SD & Average & SD & \multicolumn{2}{c|}{ Average } & SD & $\mathrm{F}$ & $\mathrm{p}$ \\
\hline $\begin{array}{l}\text { The } \\
\begin{array}{l}\text { Environment } \\
\text { of AE }\end{array}\end{array}$ & 2.214 & $\mathrm{a}$ & 0.654 & 2.770 & $\mathrm{~b}$ & 0.524 & 2.106 & $\mathrm{a}$ & 1.034 & 39.248 & 0.000000 \\
\hline $\begin{array}{l}\text { The Service in } \\
\text { the Catering } \\
\text { Part }\end{array}$ & 2.270 & $\mathrm{a}$ & 0.747 & 1.911 & $\mathrm{~b}$ & 0.475 & 2.356 & $\mathrm{a}$ & 0.730 & 19.522 & 0.000000 \\
\hline Hygiene of AE & 2.206 & $\mathrm{a}$ & 0.633 & 2.020 & $\mathrm{~b}$ & 0.462 & 2.264 & $\mathrm{a}$ & 0.739 & 6.846 & 0.001131 \\
\hline $\begin{array}{l}\text { Quality of } \\
\text { meals }\end{array}$ & 2.048 & $\mathrm{a}$ & 0.674 & 2.000 & $\mathrm{a}$ & 0.681 & 2.636 & $\mathrm{~b}$ & 0.832 & 48.912 & 0.000000 \\
\hline
\end{tabular}

The best evaluated factor in the hotels is "quality of meals" with the note of 2.05, followed by factor "hygiene of AE" and "environment of AE "with average note of 2.2. On the other hand "service in the catering part" is the worst evaluated factor with an average note of 2.27 .

The order of the factors in the accommodation establishment type guesthouse is different by expectation. The best evaluated factor is the "hygiene in accommodation establishment" with average note of 1.9 followed by factors the "quality of the meals" with a note of 2.0 and the "service in the catering part" with note of 2.02. The worst evaluative factor, the "environment of the accommodation establishment", achieved the average note of 2.77. In that case, we can explain the different order by the more hospitable and friendly attitude of the staff and the provision of specific services for the clients. The worst evaluated factor, the "environment in accommodation establishment", could relate to the obsolescence of the overall image of these establishments. The "environment of accommodation" That factor was contrary to the expectations positively evaluated in category of the campsites. The average note achieved was 2.10 . The "Service in catering part" rated by average note 2.26 and 2.35 was achieved for the "hygiene in accommodation establishment" factor where our expectations were also more negative. On the contrary, the evaluation of the "quality of meals" factor with a note of 2.63 was in compliance with our expectations. Beyond that, this result was the worst of all of the cited results which correspond with our assumption.

The generally positive evaluation of campsites corresponds with the location of several campsites from the observed area in the top 10 of evaluated camps in the Czech Republic in 2010, where clients evaluate campsites in several categories. The results achieved by these campsites in 2010 have even improved in 2011 and two of them were placed in the top 
three. The positive evaluation could also correspond with low expectations of campsites' guests. Such guests are often less likely to judge a worse experience unfavourably (Manning 1999). This finding is also in compliance with general statement of Flood (2002): "Standards people use to evaluate a setting are influenced by their expectations for that experience."

When comparing the explored factors in particular categories, the "environment of accommodation establishment" factor was evaluated at the best in case of campsites (2.10) and, on the contrary, at the worst in category of guest houses (2.77). The results are in contradiction to the presumption of our observation. In case of the "hygiene in accommodation establishment" factor, the best evaluated category is guest house (1.91) followed by hotels (2.27) and campsites (2.35). In this case, the result confirmed our expectation when the most frequently cited advantage of the guest houses was the personal approach of the employers to clients. On the contrary, the attitude of the staff to clients was negatively perceived in case of the campsites, particularly in one campsite whose note markedly influenced the final average note for all of the campsites. A similar result was achieved in case of the "service in catering part of accommodation establishment" factor; however, the values show lower variability. As to the final evaluated factor, the "quality of meals", it is possible to interpret that it is in compliance with our expectations. A similar result was achieved for the hotel category (2.04) and the guest house category (2.00). The lowest satisfaction was achieved for the category of the campsites. In that case, these clients mostly cited the low or poor quality of the meals that were prepared with low quality ingredients as well as the small portions, not to mention the similarity of the menus in all campsites, which seemed to be the biggest problems.

The above identified factors of the perception of the quality of the offered services explain an important part of the variability in the answers to the questions regarding the willingness to return once again to the same accommodation establishment. The model was tested as significant in all cases (Table 3, Table 4 and Table 5).

Table 3 Hotels. Overall Adaptability - the Results of Multiple Linear Regression.

\begin{tabular}{|l|c|r|r|c|c|}
\hline & \multicolumn{1}{c|}{$\mathrm{S}$} & \multicolumn{1}{c|}{$\mathrm{f}$} & \multicolumn{1}{c|}{ S/f } & F & $\mathrm{p}$ \\
\hline Regression & 135.6181 & 4 & 33.90453 & 91.51756 & 0.00 \\
\hline Residual & 151.1518 & 408 & 0.37047 & & \\
\hline Total & 286.7700 & & & & \\
\hline
\end{tabular}


Table 4 Guesthouses. Overall Adaptability - the Results of Multiple Linear Regression.

\begin{tabular}{|l|c|r|c|c|c|}
\hline & S & f & S/f & F & p \\
\hline Regression & 21.38021 & 3 & 7.126736 & 20.97040 & 0.000000 \\
\hline Residual & 50.29742 & 148 & 0.339847 & & \\
\hline Total & 71.67763 & & & & \\
\hline
\end{tabular}

Table 5 Camps. Overall Adaptability - The Results of Multiple Linear Regression.

\begin{tabular}{|l|r|r|r|r|c|}
\hline & \multicolumn{1}{|c|}{ S } & \multicolumn{1}{c|}{$\mathrm{f}$} & \multicolumn{1}{c|}{ S/f } & F & $\mathrm{p}$ \\
\hline Regression & 52.8482 & 3 & 17.61606 & 45.13048 & 0.000000 \\
\hline Residual & 70.2605 & 180 & 0.39034 & & \\
\hline Total & 123.1087 & & & & \\
\hline
\end{tabular}

The highest variability was explained by means of the regression model for hotels $-47 \%$ (adjusted $\mathrm{R}^{2}=0.468$, standard error of estimate $=0.609$ ). All four factors of quality perception were identified as significant (table 6).

Table 6 The Model of the Willingness to Return to the Accommodation Establishment Hotels. The Result of the Multiple Linear Regression described in Table 3.

\begin{tabular}{|l|c|c|c|c|}
\hline & $\mathrm{b}$ & S.E. & $\mathrm{t}(408)$ & $\mathrm{p}$ \\
\hline abs. & 5.328 & 0.162 & 32.929 & 0.000000 \\
\hline $\begin{array}{l}\text { The Environment } \\
\text { of theAE }\end{array}$ & -0.405 & $\begin{array}{c}0.0 \\
51\end{array}$ & -7.978 & 0.000000 \\
\hline $\begin{array}{l}\text { The Hygiene in } \\
\text { the AE }\end{array}$ & -0.425 & 0.049 & -8.638 & 0.000000 \\
\hline $\begin{array}{l}\text { The Quality of } \\
\text { the Meals }\end{array}$ & -0.336 & 0.045 & -7.394 & 0.000000 \\
\hline $\begin{array}{l}\text { The Service in the } \\
\text { Catering Part }\end{array}$ & -0.223 & 0.045 & -4.955 & 0.000001 \\
\hline
\end{tabular}

The very high percentage of the explained variability was identified by means of the multiple linear regression, also for campsites- $42 \%$ (adjusted $\mathrm{R}^{2}=0.420$, standard error of estimate $=0.625$ ). This model comprises, after that the outlying values were removed, three variables: the service in the catering part of accommodation establishment, the environment of the establishment and quality of meals (table 7). 
Table 7 - The Model of the Willingness to Return to the Accommodation Establishment Campsites. The Result of the Multiple Linear Regression described in table 5.

\begin{tabular}{|l|c|c|c|c|}
\hline & $\mathrm{b}$ & S.E. & $\mathrm{t}(180)$ & $\mathrm{p}$ \\
\hline abs. & 4.175 & 0.179 & 23.289 & 0.000000 \\
\hline $\begin{array}{l}\text { The Service in } \\
\text { the Catering } \\
\text { Part }\end{array}$ & -0.464 & 0.084 & -5.528 & 0.000000 \\
\hline $\begin{array}{l}\text { The } \\
\begin{array}{l}\text { Environment of } \\
\text { the AE }\end{array}\end{array}$ & -0.165 & 0.058 & -2.834 & 0.005124 \\
\hline $\begin{array}{l}\text { The Quality of } \\
\text { the meals }\end{array}$ & -0.151 & 0.064 & -2.360 & 0.019360 \\
\hline
\end{tabular}

The regression model for the guest houses explains the lowest percentage of the variability in the willingness to make a return visit, but it still remains relatively high $-28 \%$ (adjusted $\mathrm{R}^{2}=0.284$, standard error of estimate $=0.583$ ). The model comprises, after that the outlying values were removed, three variables: the environment of the establishment, quality of meals and hygiene of the accommodation establishment (table 8).

Table 8 The Model of the willingness to return to the accommodation establishment Guest Houses. The result of the multiple linear regression described in Table 4.

\begin{tabular}{|l|c|c|c|c|}
\hline & $\mathrm{b}$ & S.E. & $\mathrm{t}(148)$ & $\mathrm{p}$ \\
\hline abs. & 4.881 & 0.315 & 15.491 & 0.000000 \\
\hline $\begin{array}{l}\text { Environment } \\
\text { of AE }\end{array}$ & -0.473 & 0.094 & -5.025 & 0.000001 \\
\hline $\begin{array}{l}\text { Quality of } \\
\text { meals }\end{array}$ & -0.272 & 0.072 & -3.795 & 0.000215 \\
\hline $\begin{array}{l}\text { Hygiene in } \\
\text { AE }\end{array}$ & -0.238 & 0.104 & -2.288 & 0.023541 \\
\hline
\end{tabular}

The multiple linear regression confirmed that the assessment of the quality is done on the level of the assessment of partial elements of the services quality (Yang, Jou, Cheng, 2011). The model for particular types of establishment comprises at least three of four indentified factors and even all four factors in case of hotels.

The main component of the willingness to revisit is in case of the guesthouses is the perception of the environment of the accommodation establishment, which relates to their substance and their market positioning, oriented, first of all, to the selected type of client (Houghton 1994). This is not the case of campsites; the strongest factor here is the service in the catering part. This could be caused by generally low or even very low quality of the accommodation services in the campsites; however that is considered to be "standard" by 
the clients (Gastroplus, 2012),. So the quality of the services in the catering part becomes the differentiating variable.

\section{The Perception of the Relative Value}

The relative value was first evaluated for the particular types of studied accommodation establishments $($ Chi-square $=37.916 ;$ number of degrees of freedom $=2 ; p<0.001 ;$ table 9)

Table 9 Proportion of the Answers on Question of Relative Value of the Services According to the Type of Accommodation Establishment

\begin{tabular}{|l|c|l|l|}
\hline & hotel & guest house & campsite \\
\hline quality is higher & $36.48 \%$ & $82.26 \%$ & $53.76 \%$ \\
\hline quality is lower & $63.52 \%$ & $17.74 \%$ & $46.24 \%$ \\
\hline
\end{tabular}

The clients are distinctively more critical in the case of the hotels when $63.5 \%$ of them state that price is higher than expected quality. The opposite situation was identified in the category of the guest houses where $82.3 \%$ of the clients stated that the quality is higher than expected with the price offered. The proportion of the two answers is approximately balanced in the case of the campsites, which shows a relative satisfaction with services that have been delivered. There is a recent change of the preferences of the guests as pointed out (e.g. Vystoupil and Šauer 2011). When there is a failure in expected services, the customers are likely to hold higher expectations for service recovery from a service firm that is delivering a superior level of service quality (Kelley and Davis, 1994); i.e. clients are more critical and more demanding for the recovery in hotels than e.g. in guesthouses or even in campsites.

It is quite surprising that, in the cases of demographic segmentation criteria, no statistically important difference was identified among the partial segments, according sex and age. On the other hand, differences in the perception of the relative value were identified in case of all of the surveyed behaviourist segmentation criteria, except for the main purpose of the travel.

According to the number of nights spent, the current value for money rating is the lowest among clients staying for 3 to 5 nights. Thereafter, the positive perception increases and the highest current value for money rating is among those clients with the longest stay in accommodation establishment. (Chi-square $=9,052$, number of degrees of freedom $=3, p<$ 0.05 ; table 10). Satisfaction is higher in case of shorter stay (for one or two nights) as well. 
Table 10 The Proportion of the Answers on the Question of Relative Value of the Services According to the Number of Nights Spent.

\begin{tabular}{|l|c|c|c|l|}
\hline & $1-2$ & $3-4$ & $5-6$ & 7 and more \\
\hline $\begin{array}{l}\text { The quality is } \\
\text { higher }\end{array}$ & $54.55 \%$ & $40.28 \%$ & $49.66 \%$ & $72.41 \%$ \\
\hline $\begin{array}{l}\text { The quality is } \\
\text { lower }\end{array}$ & $45.45 \%$ & $59.72 \%$ & $50.34 \%$ & $27.59 \%$ \\
\hline
\end{tabular}

Table 11 The Proportion of the Answers on the Question of Relative Value of the Services According to the Repeating of $\mathrm{V}$ isit.

\begin{tabular}{|l|c|c|c|l|}
\hline & $\mathbf{1 x}$ & $\mathbf{2 x}$ & $\mathbf{3 x}$ & $\mathbf{4 x}$ and more \\
\hline The quality is higher & 42.42 & 42.02 & 52.27 & 84.62 \\
\hline The quality is lower & 57.58 & 57.98 & 47.73 & 15.38 \\
\hline
\end{tabular}

It is possible to find higher percentage of positive answers with an increasing number of visits; that means the evaluation is better, the more often the client comes to stay in the respective accommodation establishment (Chi-square $=30.274$, number of degrees of freedom $=3, \mathrm{p}<0.001$; table 11). This finding is completely in accordance with general fact that a satisfied client comes back again (Jones and Sasser, 1995).

Table 12 The proportion of Answers on the Question of the Relative Value of the Services According to Their Being Accompanied.

\begin{tabular}{|l|c|c|c|c|c|c|}
\hline & Alone & Family & $\begin{array}{c}\text { Boy/ } \\
\text { girlfriend }\end{array}$ & $\begin{array}{c}\text { Business } \\
\text { partner }\end{array}$ & $\begin{array}{c}\text { Group of } \\
\text { friends }\end{array}$ & $\begin{array}{c}\text { Organized } \\
\text { group }\end{array}$ \\
\hline $\begin{array}{l}\text { The quality is } \\
\text { higher }\end{array}$ & 75 & 54.21 & 59.09 & 47.06 & 52.63 & 36.36 \\
\hline $\begin{array}{l}\text { The quality is } \\
\text { lower }\end{array}$ & 25 & 45.79 & 40.91 & 52.94 & 47.37 & 63.64 \\
\hline
\end{tabular}

The current value for money rating according to their accompaniment is lower in the case of organized groups, business partners and groups of friends (Chi-square $=11.106$, number of degrees of freedom $=5, \mathrm{p}<0.05 ;$ table 12 ).

$\mathrm{T}$ results show in total that individual guests are more satisfied with the quality and, by contrast, those guests from organized groups are the less satisfied ones within all guesttypes. 


\section{CONCLUSIONS}

The survey in accommodation establishments brought us successfully to the identification of four factors of the perception of the quality of services offered in those establishments (only accommodation and catering services were considered). The most important factor of evaluation of the quality of services provided in accommodation establishments emerged to be the factor "environment of the accommodation establishment". Other important factors are the hygiene of the accommodation establishment, service in the catering part of the accommodation establishment and quality of meals.

Multiple linear regression confirmed that the assessment of quality is done on the level of the assessment of partial elements of the services quality (Yang, Jou, Cheng, 2011) - model for particular types of establishment comprises at least three of four indentified factors and even all four factors in case of hotels.

Clients expect provided service of certain quality level for their money. The best rated category of accommodation establishments are the guest houses followed by the campsites. Category of the hotels was the worst perceived. The other area where the current value for money rating was proved is the "number of nights" criterion. The authors have proven that clients with longer stays demonstrate their higher satisfaction. As for the criterion of the return visit, the better perception is the characteristic for those clients who return more times or who repeatedly use the services of an accommodation establishment. In case of the "being "accompanied" criterion, the best perception of the value for money is by those clients who stay in the accommodation establishment alone. The impact of the gender criteria, the age factor and the purpose of travel is impossible to prove. The discovered information shows that the measure of evaluation of the relative quality based spent money depends on the very experience with repeated visit. The "value for money rating" indicator is the more important one to be used in present situation, where many clients are willing to spend less money for their visit. Some problems of dissatisfaction should not be expensive and costly to solve (Baum, 2002). Oftentimes, there is no need for a huge amount of money to be spent in order to achieve a good rating from the clients and to have these same clients willing to come back. It is enough to be in the right place and have hospitable employees who are available (Sigala, 2003). 


\section{LITERATURE}

Akbaba, A. Measuring service quality in the hotel industry: A study in a business hotel in Turkey. International Journal of Hospitality Management. Vol. 25, No. 2, June 2006, pp. $170-192$

Baker, D.A., Crompton, J.L. (2000). Quality, satisfaction and behavioral intentions. Annals of Tourism Research, 27, 785-804.

Baum, T. (2002). Skills and training for the hospitality sector: a review of issues. Journal of Vocational Education \& Training, 54, 343-364.

Beránek, J., Kotek, P. (2007). Řizení hotelového provozu. Praha: Grada.

Bigné , J.E, Sánchez, M.I., Sánchez, J. (2002). Tourism image, evaluation variables and after purchase behaviour: inter-relationship Tourism Management, 22, 607-616.

Boella, M. J.(2003). Human resource management in the hospitality industry. Chentenham: Nelson Thornes.

Bučeková, I. (2001). Model lokalizácie hotelov na území vel'kých miest - na príklade Bratislavy. Ekonomická revue cestovného ruchu, 34, 17-27.

Bučeková, I. (2007). Vývoj priestorovej štruktúry siete hotelov na území Bratislavy. Geografický časopis, 59, 65-81.

Chen, C., Tsai, D. (2007). How destination image and evaluative factors affect behavioral intentions? Tourism Management, 28, 1115-1122.

Chi, C. G. Qu, H. (2008). Examining the structural relationships of destination image, tourist satisfaction and destination loyalty: An integrated approach. Tourism Management, 29, 624-636.

Collin, P.H.(1994). Dictionary of Hotels, Tourism and Catering Management. Teddington. Peter Collin Publishing.

Čertík, M. (2001). Cestovní ruch - vývoj, organizace a řízení, Praha: OFF.

Flood, J.P. Influence of Benchmarking on Wilderness Visitor and Manager Perceptions of Campsite Conditions. Proceedings of the 2002 Northeastern Recreation Research Symposium, 2002. pp. 165-172

Foret, M., Klusáček, P., (2011). The importance of the partnership and cooperation in the regionaldevelopment exampled on Znojmo region, Acta Universitatis Agriculturae et Silviculturae Mendelianae Brunensis, 59(4), 79-85.

Foster, R.V. T. (2002). Jak získat a udržet zákazníka. Praha: Computer Press.

Gastro plus (2012). Kempy nenabízí kvalitu? Realita je už několik let jiná. Retrieved March 15, 2012, from http://www.gastroplus.cz/novinky/kempy-nenabizi-kvalitu-realita-jeuz-nekolik-let-jina

Gúčik, M., Patuš, P. (2005). Management ubytovacej prevádzky hotela. Banská Bystrica: Slovensko-švajčiarské združenie pre rozvoj cestovného ruchu.

Jin, L., He, Y., Song, H. (2012). Service customization: To upgrade or to downgrade? An investigation of how option framing affects tourists' choice of package-tour services. Tourism Management, 33, 266-275.

He, Y. And SONG, H., 2009: A mediation model of tourists' repurchase intentions for packaged Tourism services. Journal of Travel Research, 47, 3: 317-331.

Horner, S., Swarbrooke, J. (2003). Cestovní ruch, ubytování a stravování, využití volného času: aplikovaný marketing služeb. Praha: Grada Publishing..

Houghton, J. (1994). The structure of hospitality: a cultural explanation of industrial diversity. International Journal of Hospitality Management, 13, 327-346.

Indrová, J. a kol. (2004). Cestovní ruch I. Praha: Vysoká škola ekonomická, Oeconomica.

Jones, T.O., Sasser,W. E. (1995). Why satisfied customers defect. Harvard Business Review, $1995 . \quad$ Retrieved July 7, 2012, from 
http://scholar.google.cz/scholar?q=JONES\%2C+T.\%2C+SASSER\%2CW.++Why+sat isfied+customers+defect\&btnG $=\& \mathrm{hl}=\mathrm{cs} \&$ as_sdt $=0$

Liška, J. (1997). Ekonomika a řizení podniku společného stravování. Vyškov: VVŠ PV.

Kelley, S.W., Davis, M.A. Antecedents to customer expectations for service recovery. Journal of the Academy of Marketing Science. Vol. 22, No. 1, 1994, pp. 52-61

Kempy Nenabízí kvalitu? Realita je už několik let jiná [online]. 2012 [cit. 8-3-2012] Př́istup ke zdroji: <http://www.gastroplus.cz/novinky/kempy-nenabizi-kvalitu-realitaje-uz-nekolik-let-jina >

MANAGEMENT CONSULTING GROUP, S.R.O. (2008). Pohostinství pro cestovní ruch Retrieved 3/2012, from http://www.mmr.cz/Cestovni-ruch/ProgramyDotace/Programovaci-obdobi-2004---2006/Operacni-program-Rozvoj-lidskychzdroju-(OP-RLZ)/Opatreni-4-2---Specificke-vzdelavani/Knihovna

Manning, R.E. Studies in Outdoor Recreation: Search and Research for Satisfaction. Corvaillis: Oregon State University Press, 1999, 374 p. ISBN 0-870-71463-5

Meloun, M., Militký, J. (2006). Kompendium statistického zpracování dat. Praha: Academia.

Meloun, M., Militký, J., Hill, M. (2005). Počítačová analýza vícerozměrných dat v př́kladech. Praha: Academia.

Metz, R., Grünner, H., Kessler, T. (2008). Restaurace a host. Praha: Europa Sobotáles.cz.

Middleton, V. and all. (2009). Marketing in Travel and Tourism. Elsevier, 2009.

Ministerstvo pro místní rozvoj ČR (2010). Zavádění národních standardů kvality ve vybraných sektorech cestovního ruchu. Retrieved January 15, 2012, from http://www.mmr.cz/Cestovni-ruch/Informace-Udalosti/Narodni-system-kvalitysluzeb/Zavadeni-narodnich-standardu-kvality-ve-vybranych-

Navrátil J, Knotek, J., Švec, R., Pícha, K., Navrátilová, J. (2011). Návštěvnické preference naučných stezek ve velkoplošně chráněných územích. Czech Hospitality and Tourism Papers. 13, 3 - 16.

Navrátil , J. Švec, R., Pícha, K. Doležalová, H. (2012). The behaviour in decinding the lacation of tourist accommodation facilities: Tourist regions Šumava and South Bohemia. Moravian Geographical Reports, - in print

Navrátil, J., Pícha, K. (2013). Factors influencing willingness to recommend a visit to waterenhanced tourist attractions in Central-European mountainous and submontane landscapes. In J. Kozak, \& K. Ostapowicz (Eds.), Integrating Nature and Society towards Sustainability. Springer (in press).

Navrátil, J., Pícha, K., Hřebcová, J. (2010). The importance of historical monuments for domestic tourists: The case of South-western Bohemia. Moravian Geographical Reports 18, 14-30.

Novacká, L. (2010). Cestovný ruch, technika služeb, delegát a sprievodca. Bratislava: Ekonom.

Nusair, K., Hua, N. (2010). Comparative assessment of structural equation modeling and multiple regression research methodologies: E-commerce kontext. Tourism Management, 31, 314-324.

Orieška, J. (2010) Služby v cestovním ruchu. Praha: Idea servis.

Petrick, J. F. (2004a) First timers' and repeaters' perceived value. Journal of Travel Research, 43(1), 29-38.

Petrick, J. F. (2004b). The roles of quality, perceived value and satisfaction in predicting cruise passengers' behavioral intentions. Journal of Travel Research, 42(4), 397-407.

Petrick, J. F., Morais, D. D., \& Norman, W. C. (2001). An examination of the determinants of entertainment vacationers' intentions to revisit. Journal of Travel Research, 40(1), 41-48. 
Quinn,G.P., Keough, M.J. (2002). Experimental Design and Data Analysis for Biologists. Cambridge, Cambridge University Press

Rothenberger, S. (2006). Measuring the relative importance of service dimensions in theformation of price satisfaction and service: A case study in the Hospitality and Hotel Industry. Scandinavian Journal of Hospitality and Tourism.6, p.179

Ryglová, K., Burian, M., Vajčnerová, I. (2011). Cestovní ruch - podnikatelské principy a př́ležitosti v praxi. Praha: Grada Publishing.

Saleh, F. (1991). Analysing service quality in the hospitality industry using the SERVQUAL model. Service Industries Journal, 11, 324-345.

Salerno, N. (2010). Hotel Marketing Coach. Retrieved May 10, 2011, from http://www.hotelmarketingcoach.com/20Management.htm

Sigala, M. (2003). Customer Relationship Management in Hotels. Implementing Customer Relationship Management in the Hotel Sectors: Does „IT“ always matter Retrieved July 6, 2012, from http://www.csrc.lse.ac.uk/asp/aspeic/20030143.pdf

Simpson, P.M., Siguaw, J.A. (2008). Destination Word of Mouth. The Role of Traveler Type, Residents, and Identity Salience. Journal of Travel Research, 47, 167-182.

Stárek, R. (2011). Cesta z krize? Kvalita, inovace, nápady. In Svět gastro \& hotel 2011. Retrieved March 6, 2012, from http://www.gastro-hotel.cz/hotelnictvi/cesta-z-krizekvalita-inovace-napady

Stárek, V., Vaculka, J. (2008). Ubytovací úsek v oblasti cestovního ruchu. Retrieved 4/2012 from http://www.mmr.cz

Šípková, I.(2007) . Manažérstvo kvality. Top hotelierstvo. Media ST.

Tipping, M., Bishop, E.M. (1999). Probabilistic Principal Component Analysis. Journal of the Royal Statistical Society, 61, 485-689.

Vogt, C.A., Fesenmaier, D.R. Tourists and retailers' perceptions of services. Annals of Tourism Research. Vol. 22, No. 4, 1995, pp. 763-780

Vystoupil, J., Šauer, M. (2011). Hosté a návštěvnost (selektivní faktory cestovního ruchu). In Aktuální trendy cestovního ruchu v kontextu řešení regionálních disparit (pp.5159). Praha : Vysoká škola hotelová v Praze 8. VŠH.

Weaver, D., Oppermann, M. (2000). Tourism Management. Queensland: School of Tourism \& Hotel Management

Yang, C., Jou, Y., Cheng, L. (2011) Using integrated quality assessment for hotel service quality. Qual Quant 45, 349-364.

Yuan, J., Jang, S. (2008) The effects of quality and satisfaction on awareness and behavioral Intentions: Exploring the role of a wine festival. Journal of Travel Research, 46(3), 279-288.

Zaithaml, V.A. (1988). Consumer Perceptions od Price, Quality, and Value: A Mens-End Model and Synthesis of Evidence. Journal of marketing, 52, 2-22

Zimáková, B. (2010). Kvalita služeb v gastronomii a její řízení.In Hotelnictví, turismus a vzdělávání 2010 Praha: Vysoká škola hotelová v Praze 8. 251 - 259

Zvára, K. (2008). Biostatistika. Praha: Univerzita Karlova v Praze. 